\title{
Reactive Coating of Dolomite on Alumina Substrates
}

\author{
A. H. de Aza, ${ }^{a}$ P. Pena ${ }^{a} \&$ J. S. Moya ${ }^{b}$ \\ anstituto de Cerámica y Vidrio, CSIC, Arganda del Rey, 28500 Madrid, Spain \\ 'bnstituto de Ciencia de Materiales de Madrid, CSIC, Cantoblanco, 28049 Madrid, Spain
}

(Received 3 June 1996; revised version received 15 September 1996; accepted 23 September 1996)

\begin{abstract}
The feasibility of using reactive coating of dolomite to obtain an oriented $\mathrm{CaAl}_{12} \mathrm{O}_{19}$ (hibonite) coating on alumina substrates has been shown. The textured hibonite grains grow oriented along the [110] direction on the alumina substrate. By using single crystal of sapphire it has been proved that the orientation of the hibonite layer is not dependent upon the crystal orientation of the alumina substrate. Alumina-alumina sandwiches with a weak interface have been prepared using this reactive coating technique. (C) 1997 Elsevier Science Limited.
\end{abstract}

\section{Introduction}

Modification of monolithic substrate surfaces by coating with a substance different from that of the bulk is currently an important technological issue in structural as well as in functional applications such as thermal and chemical barriers, wear resistance and tribology, environmental sensors, fibrereinforced ceramic composites, catalysis, etc. ${ }^{1}$

Ceramic coatings can be used to enhance the mechanical, chemical, electrical, optical or thermal properties of substrates, or to impart physical and mechanical properties to the substrates not normally possessed by the substrate itself.

Although a wide variety of surface modification techniques are available, e.g. thermal spray processes, sol-gel or slurry methods, chemical vapour deposition (CVD), physical vapour deposition (PVD), etc., it is generally very difficult to modify the surface to any significant depth (i.e. $>2 \mu \mathrm{m}$ ) by these routes. This fact limits the adhesion and the possible applications of the resulting coated materials. The solution of this problem depends on an increased understanding of chemical and mechanical bonding at the coating-bulk interface.
Calcium hexaluminate $\left(\mathrm{CaAl}_{12} \mathrm{O}_{19} \text {, hibonite }\right)^{2}$ is isostructural with the mineral magnetoplumbite; both consist of a $\beta-\mathrm{Al}_{2} \mathrm{O}_{3}$ type unit cell built up from two blocks that are isostructural with spinel. These spinel type blocks are separated by a mirror plane, or 'conduction plane', with stabilizing cation and oxygen anions, but they differ in the arrangement of the stabilizing cations and oxygen anions in the mirror plane. Hibonite exhibits very promising technological properties, since many cations are available as constituents of the mirror plane. Moreover, some of them can be combined in the same lattice without destroying the hexaluminate structure. Hibonite is phase-compatible with alumina up to the peritectic point $\approx 1800^{\circ} \mathrm{C}$ and the two have very close average thermal expansion coefficients. ${ }^{3}$

Hibonite presents a wide range of solid solutions with iron oxides and transition cations containing slags, ${ }^{4}$ adequate chemical resistance in alkaline environments, high stability in reducing atmosphere $^{5}$ and low solubility in several multicomponent systems. ${ }^{4-6}$ Recently hibonite-based materials have found new applications in the field of nuclear waste storage ${ }^{7}$ and catalysis. ${ }^{8}$ Further applications could be found in the field of solid state ionic conductors due to its $\beta$-alumina defect structure. ${ }^{2}$

In the present work we demonstrate reactive coating as a feasible route to coat an alumina substrate with a textured layer of hibonite, starting from a reactive coating of dolomite, $\mathrm{CaMg}\left(\mathrm{CO}_{3}\right)_{2}$. The sequence of phases appearing and the mcchanism of the interface reaction are explained on the base of the $\mathrm{MgO}-\mathrm{Al}_{2} \mathrm{O}_{3}-\mathrm{CaO}$ equilibrium diagram. ${ }^{9}$

Additionally, due to the low cost of dolomite and the simplicity of the overall process, a new route to develop high-temperature oxidation-resistant, alumina fiber-reinforced alumina matrix composites or multilayer composites with a weak interface is also proposed. 


\section{Experimental Procedure}

A $98 \%$ dense polycrystalline alumina block, obtained by sintering at $1600^{\circ} \mathrm{C}$ for $2 \mathrm{~h}$ of commercially available $>99.6$ pure alumina powder (Alcoa CT 3000 SG, Pittsburgh, Pa, USA) was used. Cylindrical plates $6 \mathrm{~mm}$ in diameter and $2 \mathrm{~mm}$ thick were diamond-machined from these blocks. The corresponding surfaces were subsequently polished to a relief of $1 \mu \mathrm{m}$.

After polishing and cleaning, these plates were coated by screen printing with a suspension of natural dolomite, $\mathrm{CaMg}\left(\mathrm{CO}_{3}\right)_{2}$, (Prodomasa, Spain) with $30.29 \mathrm{wt} \% \mathrm{CaO}, 22.05 \mathrm{wt} \% \mathrm{MgO}$, and 0.018 wt $\% \mathrm{SiO}_{2}$ and $0.011 \mathrm{wt} \% \mathrm{Al}_{2} \mathrm{O}_{3}$ as main impurities, a specific surface area of $2.5 \mathrm{~m}^{2} / \mathrm{g}$, and a particle size $<5 \mu \mathrm{m}$. This suspension was prepared by mixing ethylene glycol $(55 \mathrm{wt} \%)$ and the dolomite powder $(45 \mathrm{wt} \%)$ with $1 \mathrm{wt} \%$ defloculant (Produkt KV 5088, Zschimmer \& Co. Chemische Fabriken, Lanstein/Rhein, Germany) in an agate mortar. Different alumina substrates were screen printed and dried at $80^{\circ} \mathrm{C}$ for $48 \mathrm{~h}$. The coated substrates were fired at $1550^{\circ} \mathrm{C}$ and $1650^{\circ} \mathrm{C}$ for different times.

A similar experiment was carried out using a single crystal of sapphire (Insaco Inc., USA) as a substrate. The coated surface was the (001) plane and the heat treatment was made at $1650^{\circ} \mathrm{C}$ for $4 \mathrm{~h}$.

Sandwich type specimens were prepared with the geometry shown in Fig. 1, using polycrystalline alumina plates and then fired at $1650^{\circ} \mathrm{C}$ for $4 \mathrm{~h}$ with a load on the top to supply a small pressure of $2 \times 10^{5} \mathrm{~Pa}$ in order to promote good contact between the two surfaces.

Reactions of $\mathrm{Al}_{2} \mathrm{O}_{3}$ with dolomite are actually reactions with a fine-grained mixture of $\mathrm{CaO}$ plus $\mathrm{MgO}$ since decomposition of dolomite precedes its reaction with the substrate.

After firing, the specimens were mounted in epoxy resin, and the cross-sections were progressively diamond polished down to $1 \mu \mathrm{m}$. Phase analyses were performed using reflected-light microscopy (RLM) (Carl Zeiss D-7082 Oberkochen), and using X-ray diffraction (XRD) (Siemens D5000-Kristalloflex $710, K \propto=\mathrm{Cu}, \mathrm{Ni}$ filter). Individual grains and liquid phases were analysed

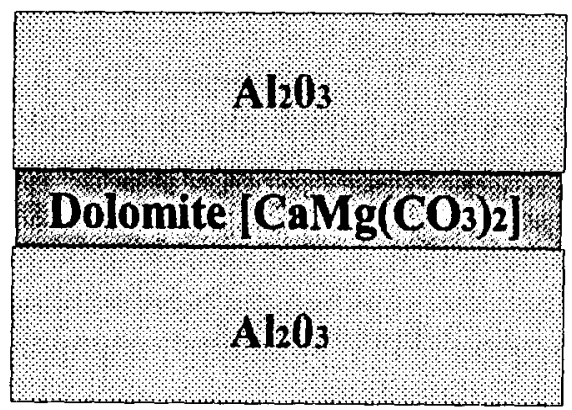

Fig. 1. Schematic representation of the sandwich type specimen. using a microprobe to determine their compositions. The microanalyses were performed on polished sections of the samples using a Scanning Electron Microscope (ISI-DS 130) with Energy Dispersive (EDAX) and Wavelength Dispersive (WDX-3PC, Microspec Corporation) spectroscope for microanalysis of emitted X-rays (EDX-WDX), using standards of each phase as reference. For better comparison of chemical composition, microanalyses were conducted under the same conditions for each specimen. Quantitative analyses were made using the ZAF (atomic number, absorption, fluorescence) correction software following the Microspec WDX-3PC program.

\section{Results}

\subsection{Reactive coating}

Figure 2 shows a general view SEM micrograph corresponding to the cross-section of the sample fired at $1550^{\circ} \mathrm{C}$ for $1 \mathrm{~min}$. In this micrograph the initial stage of the interface reaction with the formation of $\mathrm{CaAl}_{4} \mathrm{O}_{7}$ and $\mathrm{CaAl}_{12} \mathrm{O}_{19}$ textured crystals and well developed spinel grains at the top of the coating can be seen.

Figure 3(a) shows a general SEM view of the cross-section of the polycrystalline alumina substrate coated after firing at $1650^{\circ} \mathrm{C}$ for $4 \mathrm{~h}$. As observed, the upper part of the sample coating is formed by primary spinel crystals and a liquid phase. This part is practically scparated from the rest by a longitudinal crack which developed during cooling. At the bottom a well-textured thick layer of hibonite phase growing from the alumina substrate is also clearly shown. Figure 3 (b) shows a close up SEM micrograph of the interface hibonite $/ \mathrm{Al}_{2} \mathrm{O}_{3}$ where no liquid phase is detected by SEM. Grain boundary microcracks propagating through the hibonite layer along the easily cleaved basal planes perpendicular to the hibonite-alumina interface are visible. The coated surface shows a strongly oriented X-ray diffraction pattern (Fig. 3(c)). This XRD pattern shows that the hibonite is oriented in the [110] direction and the remaining $\mathrm{CaAl}_{4} \mathrm{O}_{7}$ phase is also oriented along the [100] direction.

Figure 4 shows the results obtained in a similar experiment using a [001] oriented single crystal of sapphire as a substrate instead of polycrystalline alumina. In the upper part of the sample, Fig. 4(b), we can clearly see spinel, the liquid zone, and the crack formed through the interface $\mathrm{CaAl}_{4} \mathrm{O}_{7}$ / $\mathrm{CaAl}_{12} \mathrm{O}_{19}$. At the bottom a thick layer of hibonite $(20 \mu \mathrm{m})$ growing on the sapphire substrate is also clearly shown. Figure 4(c) shows a strongly oriented diffraction pattern similar to that obtained in polycrystalline alumina. 
No chipping or interfacial cracks were detected between the oriented hibonite layer and the alumina substrates (Figs 3 and 4).

The microprobe analyses of the different crystalline phases are summarized in Table 1.
According to these results the hibonite and spinel grains present solid solutions of magnesium and aluminum cations as expected ${ }^{10}$ but the $\mathrm{CaAl}_{4} \mathrm{O}_{7}$ grains are practically free of magnesium.

Conts: 0

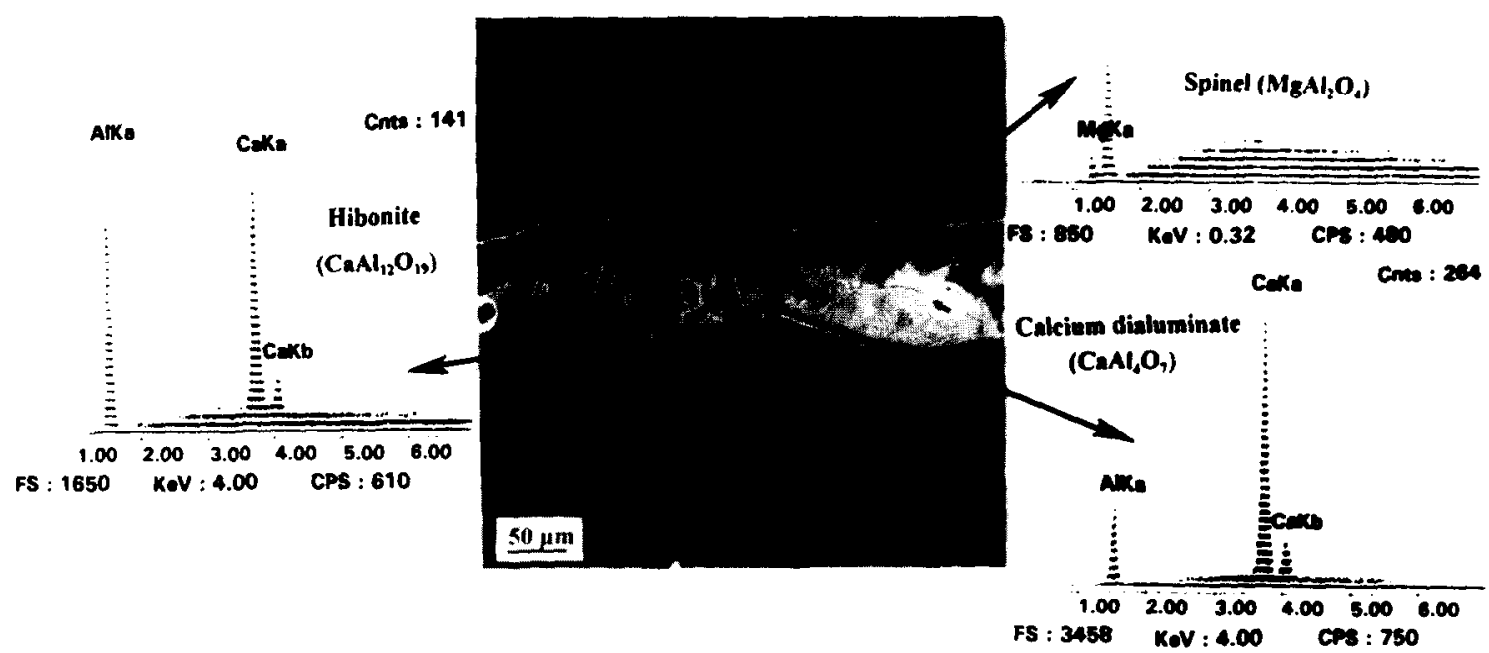

Fig. 2. SEM micrograph showing the cross-section of $\alpha-\mathrm{Al}_{2} \mathrm{O}_{3} / \mathrm{CaMg}\left(\mathrm{CO}_{3}\right)_{2}$ sample fired at $1550^{\circ} \mathrm{C}$ for 1 min and the EDAX spectra quoted on the different kind of crystals.
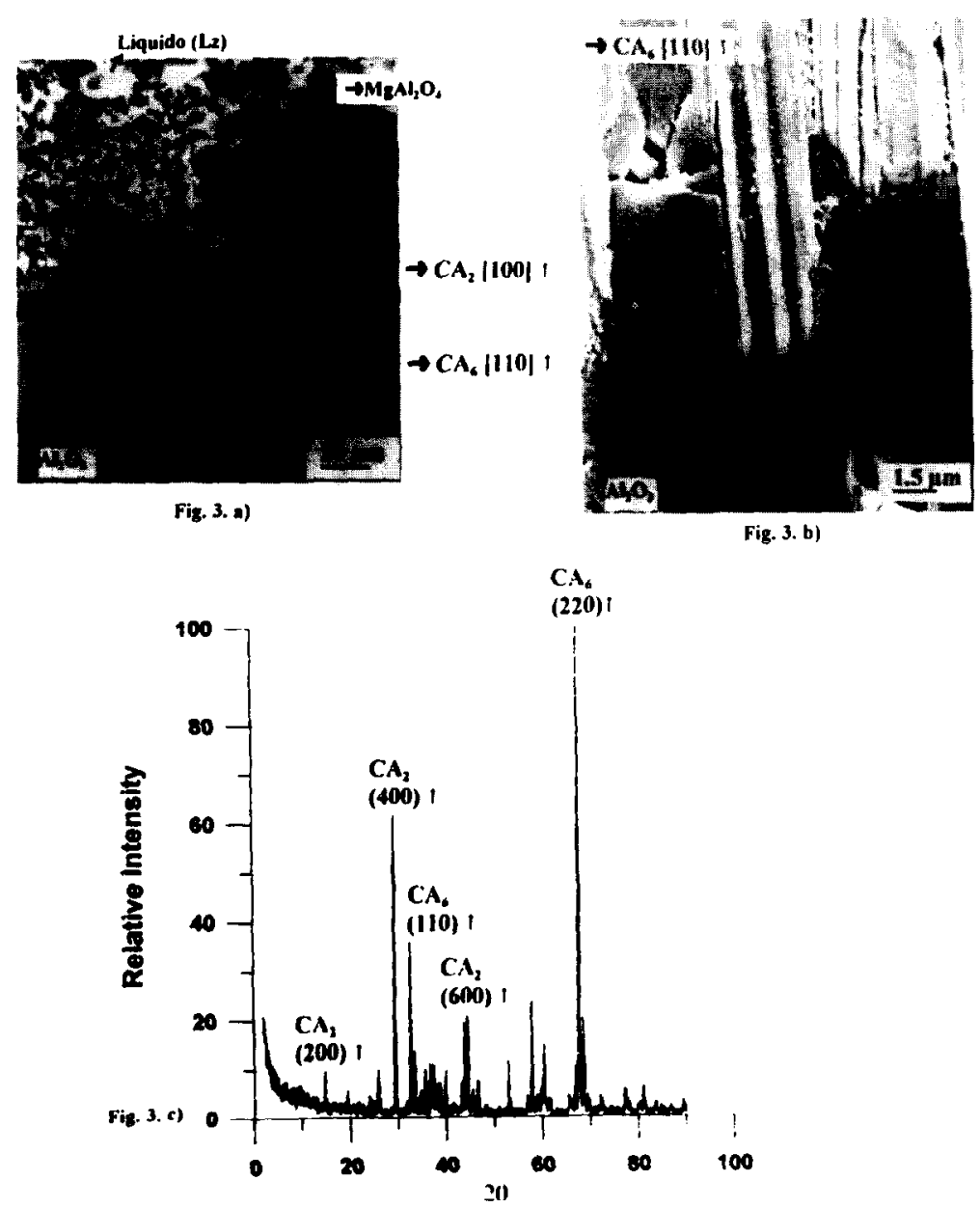

Fig. 3. (a) SEM micrograph corresponding to the cross-section of the polycrystalline alumina substrate coated with dolomite after firing at $1650^{\circ} \mathrm{C} / 4 \mathrm{~h}$. (b) Close-up SEM micrograph showing the interface between the textured hibonite crystals and the alumina substrate. (c) XRD pattern obtained on the hibonite surface showing that it is oriented in the [110] direction and the remaining $\mathrm{CaAl}_{4} \mathrm{O}_{7}$ phase that is also oriented along the [100] direction. 
Figure 5 shows the thickness of the hibonite layer formed after different heat treatments on both alumina substrates.

\section{2 'Sandwich' type specimens}

Figure 6 shows a SEM micrograph of the crosssection corresponding to an $\mathrm{Al}_{2} \mathrm{O}_{3} / \mathrm{CaMg}\left(\mathrm{CO}_{3}\right)_{2}$ $\mathrm{Al}_{2} \mathrm{O}_{3}$ sample heat treated at $1650^{\circ} \mathrm{C}$ for $4 \mathrm{~h}$. In this case the interlayer is constituted by two symetrical textured hibonite layers and an intermediate layer formed by spinel and $\mathrm{CaAl}_{4} \mathrm{O}_{7}$ grains imbedded in a glassy matrix containing microcracks. In this particular case cracks perpendicular to the alumina substrates are also visible in both hibonite layers.

Figure 7 shows the cracks generated by a Vickers indenter in the substrate close to the interface $\mathrm{Al}_{2} \mathrm{O}_{3}$ /hibonite. In this figure it can be observed that the indentation cracks cross the hibonite layer through the easily cleaving basal planes and deflect along the microcracks of the glassy-rich intermediate layer.

\section{Discussion}

The hibonite layer formation and the sequence of phase appearance at the interface reaction can be explained considering the isothermal section at $1650^{\circ} \mathrm{C}$ of the $\mathrm{MgO}-\mathrm{Al}_{2} \mathrm{O}_{3}-\mathrm{CaO}$ ternary system (Fig. 8). During heating a liquid phase appears at the interface $\mathrm{CaO} \cdot \mathrm{MgO} / \mathrm{Al}_{2} \mathrm{O}_{3}$ at temperatures as low as $\approx 1321^{\circ} \mathrm{C}$ as inferred from the $\mathrm{MgO}-\mathrm{Al}_{2} \mathrm{O}_{3}$ $\mathrm{CaO}$ equilibrium diagram. ${ }^{9}$ This liquid corresponds to the lowest eutectic point of the ternary system. This liquid changes in composition from point $\mathrm{P}$ to $\mathrm{Y}$ as the temperature rises and as the reaction between $\mathrm{CaO} . \mathrm{MgO} / \mathrm{Al}_{2} \mathrm{O}_{3}$ takes place. At this point liquid $\mathrm{Y}$ is saturated with spinel, $\mathrm{MgAl}_{2} \mathrm{O}_{4}$, and magnesia, $\mathrm{MgO}$. As reaction proceeds magnesia is dissolved and the composition of the liquid in equilibrium with spinel moves along the line $\mathrm{Y}-\mathrm{Z}$, as $\mathrm{Al}_{2} \mathrm{O}_{3}$ is dissolved. When the liquid composition reaches point $\mathrm{Z}$, it is satured in both $\mathrm{MgAl}_{2} \mathrm{O}_{4}$ and $\mathrm{CaAl}_{4} \mathrm{O}_{7}$. This last phase nucleates and grows along [100] on the
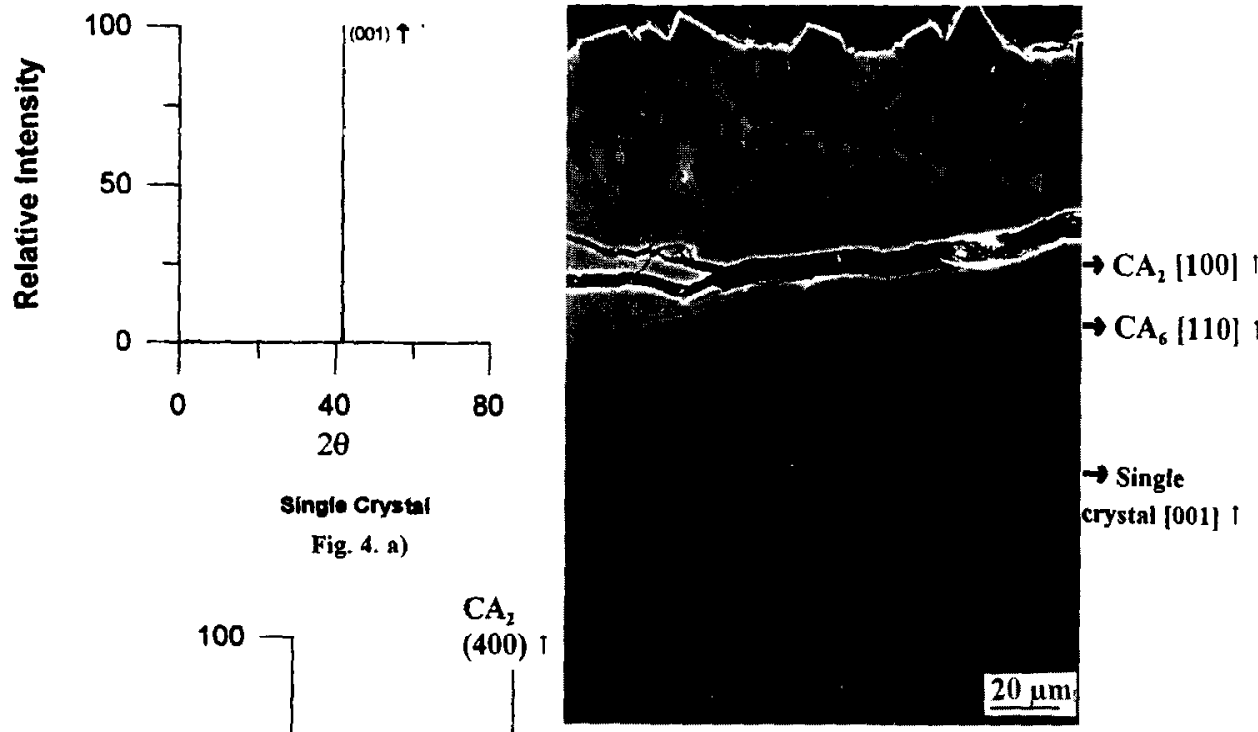

Fig. 4. b)

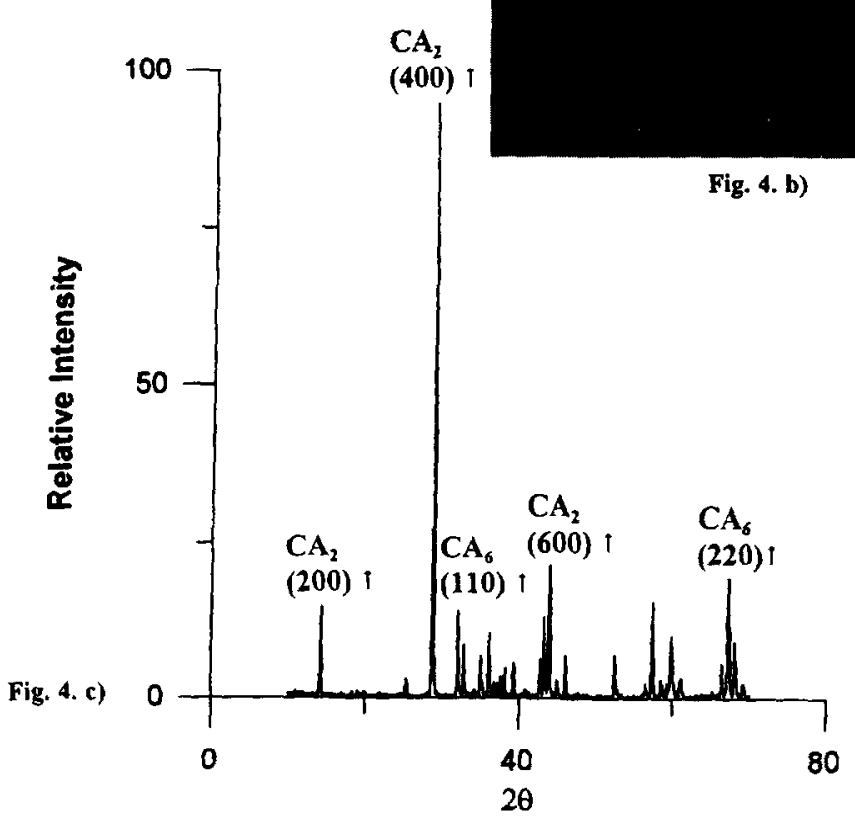

Fig. 4. (a) XRD pattern obtained on the sapphire surface, showing the [001] orientation of the single crystal. (b) SEM micrograph corresponding to the cross-section of the sapphire substrate coated with dolomite after firing at $1650^{\circ} \mathrm{C} / 4 \mathrm{~h}$, showing a thick textured hibonite layer and the crack formed through the $\mathrm{CaAl}_{4} \mathrm{O}_{7} / \mathrm{CaAl}_{12} \mathrm{O}_{19}$ interface. (c) XRD pattern of the coating showing preferential orientation along [100] and $[110]$ of $\mathrm{CaAl}_{4} \mathrm{O}_{7}$ and $\mathrm{CaAl}_{12} \mathrm{O}_{19}$ phases. 
surface of the alumina substrate as shown in Fig. 2 . This layer physically separates the spinel plus liquid from the alumina substrate. In a later step the $\mathrm{CaAl}_{4} \mathrm{O}_{7}$ reacts, in the absence of liquid, with the alumina substrate giving hibonite which is compatible with alumina. The hibonitc grains also grow oriented, but along the [110] direction. Both growing directions are in close agreement with the data reported by the pioneering study of Kohatsu et al. ${ }^{11}$ using a $\mathrm{CaO} / \mathrm{Al}_{2} \mathrm{O}_{3}$ couple diffusion system. The crystal orientation of the textured layer is not dependent upon the crystal orientation of the alumina substrate (Figs 3 and 4).

According to our results the axial direction $c$ of the hibonite layer is parallel to the alumina substrates.

The thickness of the hibonite layer was about five times larger in the polycrystalline alumina than in the sapphire (Fig. 5). This fact can be explained considering the faster grain boundary diffusion of calcium and aluminum species in the polycrystalline substrate."

As the average thermal expansion coefficient of $\mathrm{CaAl}_{4} \mathrm{O}_{7}\left(4.0 \times 10^{6}{ }^{\circ} \mathrm{C}^{-1}\right)^{3}$ is approximately half

Table 1. Microprobe analyses of the $\mathrm{CaAl}_{4} \mathrm{O}_{7}, \mathrm{CaAl}_{12} \mathrm{O}_{19}$ and $\mathrm{MgAl}_{2} \mathrm{O}_{4}$ phases formed at different temperatures on both alumina substrates

\begin{tabular}{|c|c|c|c|}
\hline $\begin{array}{l}\text { Thermal } \\
\text { treatment }\end{array}$ & $\begin{array}{c}\mathrm{CaAl}_{12}, \mathrm{O}_{19} \\
\left(\mathrm{wt}^{2} /(1)\right)\end{array}$ & $\begin{array}{c}\mathrm{CaAl}_{4} \mathrm{O}_{7} \\
\left(\mathrm{wt}^{\prime \prime \prime \prime n)}\right.\end{array}$ & $\begin{array}{c}\mathrm{MgAl}_{2} \mathrm{O}_{4} \\
\left(\mathrm{w}^{\prime} \mathrm{t}^{\prime \prime \prime(w)}\right)\end{array}$ \\
\hline $\begin{array}{l}1550^{\circ} \mathrm{C} / 1 \mathrm{~min} \\
\text { Polycrystalline } \\
\text { alumina }\end{array}$ & $\begin{aligned} \mathrm{MgO}: & 0.24 \\
\mathrm{Al}_{2} \mathrm{O}_{3}: & 90 \cdot 65 \\
\mathrm{CaO}: & 9 \cdot 10\end{aligned}$ & $\begin{array}{c}\mathrm{MgO}: 0.07 \\
\mathrm{Al}_{2} \mathrm{O}_{3}: 79 \cdot 16 \\
\mathrm{CaO}: 20 \cdot 77\end{array}$ & $\begin{array}{c}\mathrm{MgO}: 22 \cdot 77 \\
\mathrm{Al}_{2} \mathrm{O}_{3}: 77 \cdot 03 \\
\mathrm{CaO}: 0 \cdot 20\end{array}$ \\
\hline $\begin{array}{l}1650^{\circ} \mathrm{C} / 4 \mathrm{~h} \\
\text { Polycrystalline } \\
\text { alumina }\end{array}$ & $\begin{aligned} \mathrm{MgO}: & 0 \cdot 59 \\
\mathrm{Al}_{2} \mathrm{O}_{3}: & 93 \cdot 71 \\
\mathrm{CaO}: & 5 \cdot 70\end{aligned}$ & $\begin{array}{c}\mathrm{MgO}: 0.04 \\
\mathrm{Al}_{2} \mathrm{O}_{3}: 83.02 \\
\mathrm{CaO}: 16.95\end{array}$ & $\begin{array}{c}\mathrm{MgO}: 21 \cdot 40 \\
\mathrm{Al}_{2} \mathrm{O}_{3}: 78 \cdot 45 \\
\mathrm{CaO}: 0.15\end{array}$ \\
\hline $\begin{array}{l}1650^{\circ} \mathrm{C} / 4 \mathrm{~h} \\
\text { Single crystal }\end{array}$ & $\begin{array}{c}\mathrm{MgO}: 0.04 \\
\mathrm{Al}_{2} \mathrm{O}_{3}: 94 \cdot 13 \\
\mathrm{CaO}: 5.83\end{array}$ & $\begin{array}{c}\mathrm{Al}_{2} \mathrm{O}_{3}: 82.72 \\
\mathrm{CaO}: 17.28\end{array}$ & $\begin{array}{c}\mathrm{MgO}: 21 \cdot 30 \\
\mathrm{Al}_{2} \mathrm{O}_{3}: 78 \cdot 56 \\
\mathrm{CaO}: 0.13\end{array}$ \\
\hline
\end{tabular}

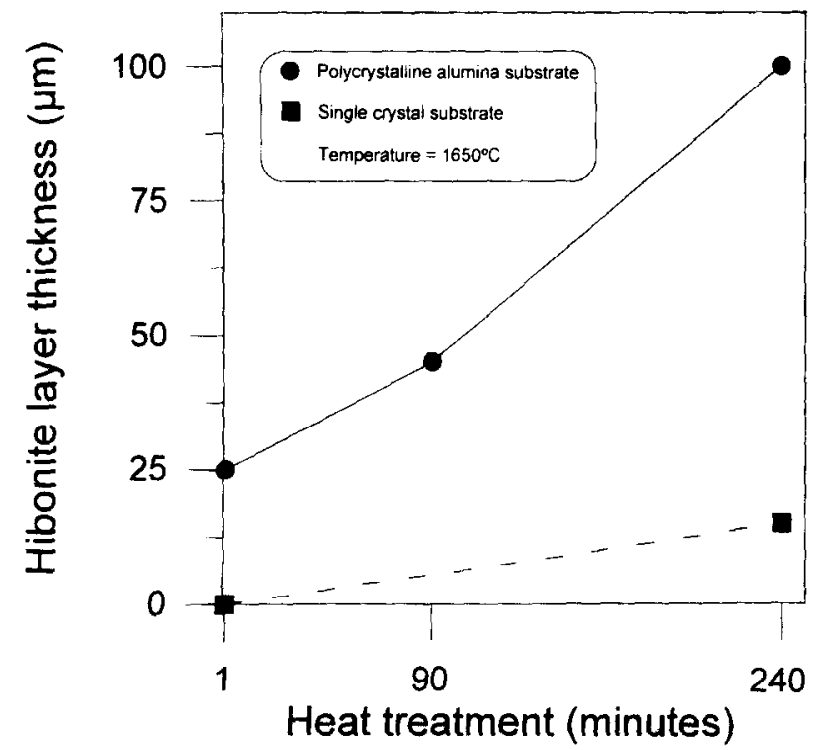

Fig. 5. Hibonite layer thickness versus heat treatments on both alumina substrates. that of $\mathrm{CaAl}_{12} \mathrm{O}_{19}\left(8.3 \times 10^{-6}{ }^{\circ} \mathrm{C}^{-1}\right)^{3}$, large stresses are generated during the cooling producing a crack parallel to the $\mathrm{CaAl}_{4} \mathrm{O}_{7} / \mathrm{CaAl}_{12} \mathrm{O}_{19}$ interface

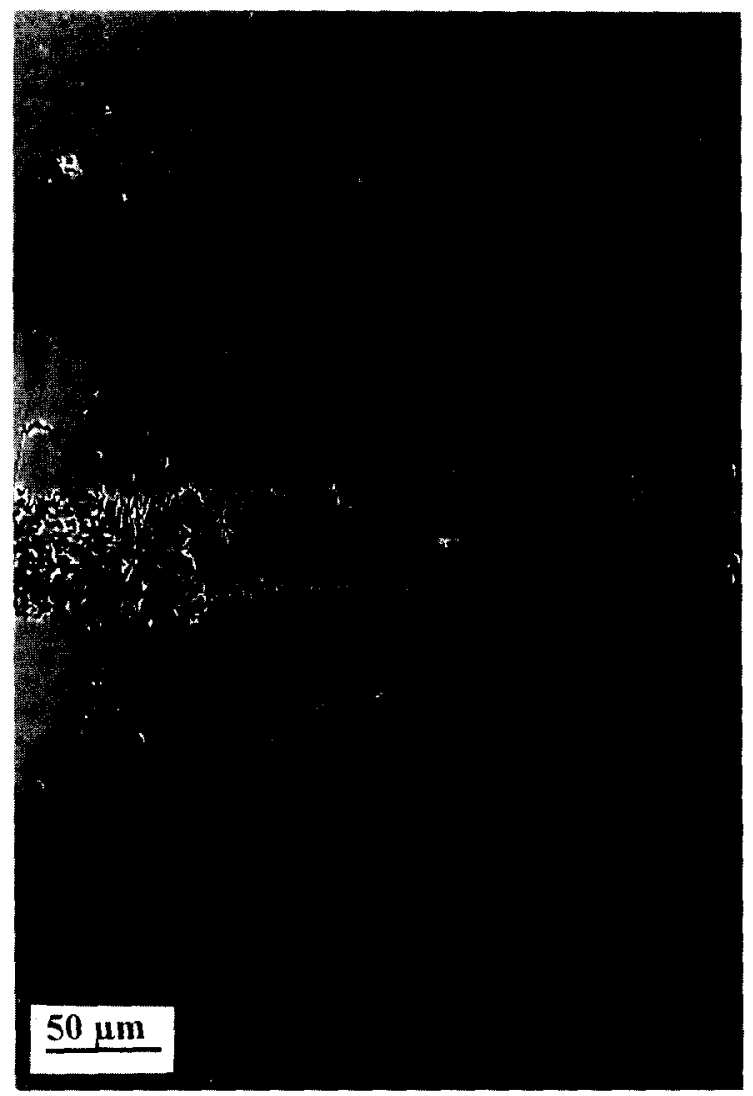

Fig. 6. SEM micrograph of the cross-section corresponding to $\mathrm{Al}_{2} \mathrm{O}_{3} / \mathrm{MgCa}\left(\mathrm{CO}_{3}\right)_{2} / \mathrm{Al}_{2} \mathrm{O}_{3}$ sample heat treated at $1650^{\circ} \mathrm{C} / 4 \mathrm{~h}$

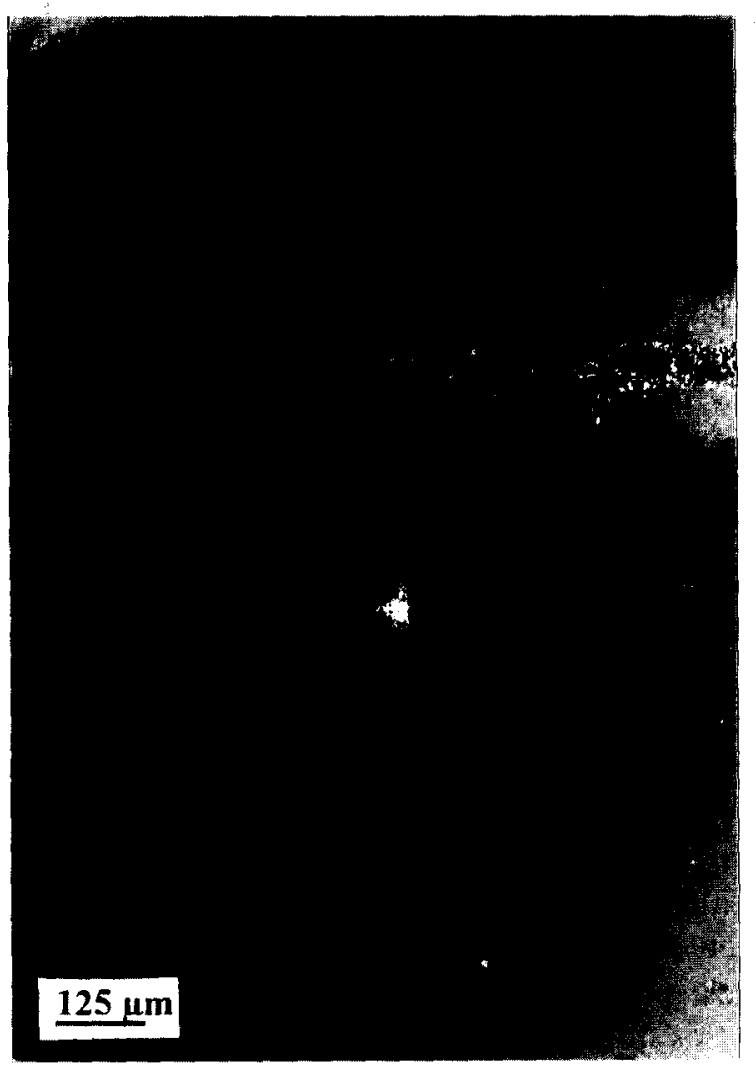

Fig. 7. SEM micrograph showing the cracks generated by a Vickers indenter in the 'sandwich' type specimen. 


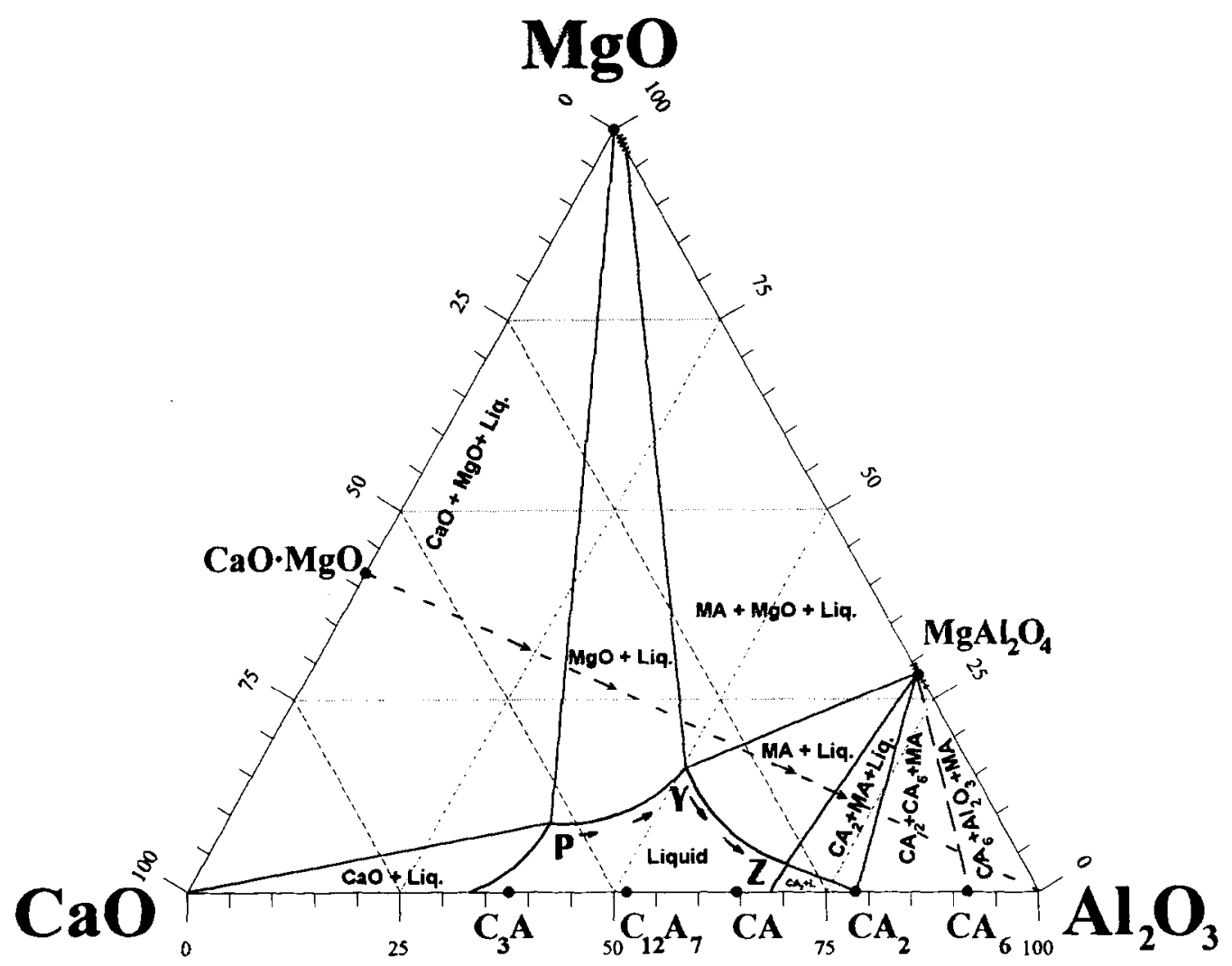

Fig. 8. Isothermal section at $1650^{\circ} \mathrm{C}$ of the $\mathrm{MgO}-\mathrm{Al}_{2} \mathrm{O}_{3}-\mathrm{CaO}$ ternary system.

as was observed in the micrographs shown in Figs 3 and 4.

Hibonite exhibits large thermal expansion coefficient anisotropy, ${ }^{12} \alpha_{\mathrm{p}(20-800)}=11.8 \times 10^{-6}{ }^{\circ} \mathrm{C}^{-1}$ and $\alpha_{\mathrm{b}(20-800)}=7.5 \times 10^{-6}{ }^{\circ} \mathrm{C}^{-1}$, where the subscripts $\mathrm{b}$ and $\mathrm{p}$ indicate basal planes and perpendicular to the basal planes respectively. Hitchcock el al..$^{13}$ have reported that single crystals of these materials show a large fracture toughness anisotropy with $K_{\mathrm{b}} / K_{\mathrm{p}} \sim 0 \cdot 1$. In the present work, the hibonite layer is preferentially oriented with its (110) planes parallel to the interfaces, consequently its basal planes are perpendicular to the interface. Due to this, during cooling the hibonite layer is subjected to tensile stress $\left(\sigma_{\mathrm{R}}=1 / 2\left[E . \Delta \alpha_{\max } \cdot \Delta T\right]\right.$ where $\left.\Delta \alpha=\alpha_{\text {alumina }}-\alpha_{\text {p(hibonite) }}=-3.8 \times 10^{-6}{ }^{\circ} \mathrm{C}^{-1}\right)$. That is, because of the hibonite's low $K_{\mathrm{b}}$ value, any defect located on the top layer surface is easily propagated as a crack perpendicular to the substrate (Figs 3 and 4). This releases the residual stresses developed at the coating interface lessening the possible development of parallel cracks and chipping.

In the case of the 'sandwich' type specimens, because of the symmetrical arrangement of the layer, microcracks develop instead of a long single crack at the interface. The mechanical stability of this joining has been qualitatively tested by Vickers indentation (Fig. 7). The indentation crack easily penetrates the hibonite layer but due to the high density of microcracks the growing crack becomes entrapped in the intermediate glassy rich layer.

Because of this fact this type of coating might be used as a weak interface in alumina-fibre-reinforced alumina matrix. In this kind of application the interface between fibres and matrix must bc sufficiently weak to allow for crack deflection and debonding at the fibre-matrix interfaces. ${ }^{14}$ Morgan et al. ${ }^{15}$ have shown a similar effect in a sapphirefibre-reinforced polycrystalline alumina matrix using monazite as a weak interface.

\section{Conclusions}

The following conclusions can be drawn:

(1) The feasibility of using a reactive coating of dolomite to obtain an oriented $\mathrm{CaAl}_{12} \mathrm{O}_{19}$ (hibonite) coating on alumina substrates has been shown.

(2) The mechanism of formation of the $\mathrm{CaAl}_{12} \mathrm{O}_{19}$ layer is explained by means of the $\mathrm{MgO}-\mathrm{Al}_{2} \mathrm{O}_{3}-\mathrm{CaO}$ system.

(3) The hibonite textured grains grow oriented along the [110] direction on an alumina substrate in the absence of any liquid phase and the orientation of the hibonite textured layer is not dependent upon the crystal orientation of the alumina substrate. 
(4) The potential application of the reactive coating of dolomite in the development of fibre-reinforced ceramic composites or multilayer composites with a weak interface that deflects a growing crack has been proved.

\section{Acknowledgements}

The authors thank A. P. Tomsia and E. Saiz from U. C. Berkeley for their assistance during the WDX analyses and S. de Aza for his helpful comments. One of the authors (A. H. de Aza) was supported by FICYT. This work has been supported by CICYT, Spain, under project number MAT-94-0974.

\section{References}

1. Eppler, R. A., Ceramic and Glasses. In Engineered Materials Handbook, Vol. 4. ASM International, The Materials Information Society, 1991, pp. 991-993.

2. Hoek, J. V., Alkali metal corrosion of alumina, thermodynamics, phase diagrams and testing. Ph.D. Thesis, Tech. University Eindhoven, Netherlands, Oct. 1990.

3. Criado, E., De Aza, S. and Estrada, D. A., Caracteristicas dilatométricas de los aluminatos de calcio. Bol. Soc. Esp. Cerám. Vidr., 1975, 14(3), 271-273.
4. Lister, D. H. and Glasser, F. P., Phase relations in the system $\mathrm{CaO}-\mathrm{Al}_{2} \mathrm{O}_{3}$-Iron Oxide Trans. Brit. Ceram. Soc. 1967, 66, 293-305.

5. Criado, E. and De Aza, S., Calcium hexaluminate as refractory material. UNITECR'91, Vol. I, pp. 566-574, 1991, Aachen, Germany.

6. Pena, P. and De Aza, S., Compatibility relations in the system $\mathrm{ZrO}_{2}-\mathrm{Al}_{2} \mathrm{O}_{3}-\mathrm{SiO}_{2}-\mathrm{CaO}$. J. Am. Ceram. Soc. $1984,67, \mathrm{C}-3-\mathrm{C}-5$.

7. Harker, A. B. and Flimtoff, J. F., Hot isostatically pressed ceramic and glasses forms for immobilizing Hanford high-level wastes. Avd. Ceram., 1984, 8, 222-233.

8. Hodge, J. D., Alkaline earth effects on the reaction of sodium with aluminium oxides. J. Electrochem. Soc., 1986, 133(4), 833-836.

9. De Aza, A. H., Pena, P. and De Aza, S., J. Am. Ceram. Soc., (submittcd).

10. Göbbels, M., Woermann, E. and Jung, J., The Al-rich part of the system $\mathrm{CaO}-\mathrm{Al}_{2} \mathrm{O}_{3}-\mathrm{MgO}$ : Part I, Phase Relationships. J. Solid State Chem., 1995, 120, 358-363.

11. Kohatsu, I. and Brindley, G. W., Solid state reactions between $\mathrm{CaO}$ and $\propto-\mathrm{Al}_{2} \mathrm{O}_{3}$. Zeitschrift für Physikalische Chemie, 1968, Neue Folge, Bd 60, S. 79-89.

12. Brooksbank, D., Thermal expansion of calcium aluminate inclusions and relation to tessellated stresses. J. Iron and Steel Institute, May 1970, 495-499.

13. Hitchcock, D. C. and De Jonghe, L. C., Fracture toughness anisotropy of sodium $\beta$-alumina. J. Am. Ceram. Soc., 1983, 11, C-204-C-205.

14. Cinibulk, M. K., Magnetoplumbite compounds as a fiber coating in oxide/oxide composites. Ceram. Eng. Sci. Proc., 1994, 15(5), 721-728.

15. Morgan, P. E. D. and Marshall, D. B., Ceramic composites of monazite and alumina. J. Am. Ceram. Soc., 1995, 78(6), 1553-1563. 